DOI: $10.19195 / 0080-3626.61 .4$

EWA CHLEBUS

\title{
ELEMENTY PRZYBYSZOWE W OPRAWACH PÓŹNOGOTYCKICH - FORMY, FUNKCJE, TERMINOLOGIA
}

Znaczenie kart przybyszowych. Zmiany układu kart przybyszowych. Różnorodność rozwiązań technicznych w oprawach późnogotyckich. Karty przybyszowe i elementy przybyszowe. Wyklejka. Karty ochronne. Zszywki. Scyzura. Wyklejenie grzbietu.

SŁOWA KLUCZOWE: introligatorstwo, oprawa gotycka, elementy przybyszowe, karty przybyszowe, wyklejki, karty ochronne

Karty przybyszowe, czyli karty dodawane przez introligatora podczas oprawiania książki, są cennym źródłem informacji dla bibliologów, kodykologów czy tegumentologów. To na nich nanoszono dawniej pieczęcie czy sygnatury biblioteczne, a także przyklejano ekslibrisy właścicieli. Na nich również spotkać można zapiski własnościowe czy empcyjne, informujące o okolicznościach zakupu książki. Powierzchnie wyklejek bywały wykorzystywane przez księgarzy do przedstawienia swojej oferty, a właściciele książek sporządzali na pustych kartach spis zawartości woluminu, komentowali jego treść, prowadzili różnego rodzaju luźne notatki czy wreszcie wykorzystywali je do spontanicznej działalności artystycznej. Ale karty przybyszowe to nie tylko czyste arkusze. Bardzo często, zarówno w późnym średniowieczu, jak i w epoce nowożytnej, wykonywano je z rękopiśmiennej lub drukowanej makulatury ${ }^{1}$. Wiele bezcennych zabytków piśmiennictwa zachowało się jedynie w formie pergaminowych fragmentów stanowiących elementy oprawy. Paradoksalnie mamy dziś wiedzę o tych rękopisach właśnie dzięki temu, że dawniej uznano je za niepotrzebne i nadano im zupełnie nową funkcję. Podobnie cenny materiał do badań nad wczesnym drukarstwem stanowią liczne, często unikatowe fragmenty druków wydobyte z opraw. I wreszcie karty

${ }^{1}$ Szerzej na temat stosowania makulatury w oprawach: N. Pickwoad, The Use of Fragments of Medieval Manuscripts in the Construction and Covering of Bindings on Printed Books, [w:] Interpreting and Collecting Fragments of Medieval Books, pod red. L.L. Brownrigg, M.M. Smith, Oxford 2000, s. 1-20. 
przybyszowe mogą również pomóc $\mathrm{w}$ datowaniu i lokalizacji miejsca wykonania oprawy. Zastosowany przez introligatora papier, czy to czysty, czy też $\mathrm{w}$ formie makulatury, wskazywać może na miejsce powstania opraw, a także związki np. z księgarzami lub oficynami wydawniczymi.

Karty przybyszowe to jedne z komponentów oprawy, które z biegiem czasu najbardziej podatne były na modyfikacje. Problematyczne może być zatem ustalenie, czy obecnie obserwowany układ tych elementów zachował się w niezmienionej, pierwotnej formie. Czyste karty papierowe, a zwłaszcza pergaminowe, często wycinano z bloku, pozyskując w ten sposób materiał piśmienniczy. Doszyty do składki wąski pergaminowy falc mógł mieć zatem pierwotnie przedłużenie w postaci karty ochronnej. Ponieważ elementy przybyszowe ulegały częstym uszkodzeniom związanym z użytkowaniem książki, z biegiem czasu poddawane bywały różnego rodzaju procesom naprawczym. Wyklejki zaklejano kartami ochronnymi lub nowymi arkuszami. Wzmacniano połączenie bloku z okładką za pomocą pasków papieru, pergaminu czy płótna. W skrajnych przypadkach wymieniano całkowicie wyklejki w trakcie prac konserwatorskich lub całą konstrukcję modyfikowano, dodając np. scyzurę bądź dodatkowe karty ochronne. Ze względu na swoją wartość historyczną wyklejki i karty ochronne były często odłączane od opraw, zwłaszcza w okresie największej popularności badań makulaturowych. Większość wydobytych fragmentów oddzielano całkowicie od opraw, tak że w wielu przypadkach nie mamy żadnych wskazówek, jaką konstrukcję kart przybyszowych zawierały ${ }^{2}$.

W oprawach późnogotyckich, powstałych w II połowie XV i na początku XVI wieku, karty przybyszowe przyjmować mogły różnorodne formy. Trzeba tu jednak zaznaczyć, że zasadniczo oprawy te cechuje duża różnorodność rozwiązań konstrukcyjnych i nie dotyczy to wyłącznie kart dodanych przez introligatora. Źródeł tego zróżnicowania doszukiwać się należy w zmianach, jakie nastąpiły w procesach wytwarzania i dystrybucji książki w II połowie XV wieku. Zwiększona produkcja książki spowodowana wynalezieniem druku z jednej strony wymagała zwiększenia liczby warsztatów introligatorskich, z drugiej zaś zmuszała do przyspieszenia pewnych zabiegów związanych z oprawą i poszukiwania nowych, bardziej efektywnych rozwiązań ${ }^{3}$. Jednocześnie spopularyzowanie modelu wędrownego rzemieślnika torowało drogę ponadregionalnemu rozprzestrzenianiu się lokalnie wypracowanych technik.

${ }^{2}$ Czasem możliwe jest jednak wnioskowanie o oprawach, z jakich wydobyto takie osierocone fragmenty makulatury, na podstawie zachowanych śladów. Por. J.M. Sheppard, Medieval Binding Structures: Potential Evidence from Fragments, [w:] Interpreting and Collecting..., s. 166-175.

${ }^{3}$ Szerzej na ten temat: N. Pickwoad, Onward and Downward: How Binders Coped with the Printing Press before 1800, [w:] A Millennium of the Book: Production, Design and Illustration in Manuscript and Print 900-1900, pod red. M. Harrisa, R. Myersa, Winchester 1994, s. 61-106 (,Publishing Pathways” 8). 
W nagromadzeniu różnorodnych rozwiązań technicznych stosowanych na oprawach późnogotyckich można jednak zaobserwować pewne prawidłowości ${ }^{4}$. Wynikają one $z$ faktu preferowania przez poszczególnych rzemieślników konkretnych technik introligatorskich. Oprawy z danego warsztatu reprezentują więc zwykle ograniczoną liczbę ,sprawdzonych” rozwiązań technicznych ${ }^{5}$. Mimo istnienia tych prawidłowości duża różnorodność występujących rozwiązań konstrukcyjnych sprawia istotny kłopot badaczom próbującym opisać oprawy. Inwencja introligatorów zdaje się przerastać próby nazwania i sklasyfikowania poszczególnych elementów oprawy. Na gruncie polskiej tegumentologii problem jest tym bardziej palący, że polskie słownictwo z zakresu oprawoznawstwa i introligatorstwa jest niezwykle ubogie, wymaga dopracowania, a w wielu przypadkach również utworzenia nowych terminów ${ }^{6}$. Przykładowo: definicje opracowane na potrzeby Encyklopedii wiedzy o książce miały być na tyle ogólne, by mogły służyć do nazywania elementów budowy zarówno książki współczesnej, jak i książki dawnej. Często są one ukute właśnie w oparciu o budowę książek współczesnych i nie do końca pasują do opisu konstrukcji stosowanych we wcześniejszych wiekach. W przypadku opraw gotyckich problem ten jest szczególnie widoczny. Badacz opraw niejednokrotnie staje przed problemem, jakim terminem określić dany składnik oprawy, a brak jasnych definicji zmusza do prób ujęcia opisowego lub też do całkowitego zignorowania nienazywalnych elementów.

Niniejsze rozważania powstały na marginesie mojej pracy nad introligatorstwem z obszaru Prus Królewskich w oparciu o analizę przeszło dwóch tysięcy opraw inkunabułów i wczesnych druków XVI-wiecznych z lokalnych księgozbiorów historycznych. Na wybranych przykładach zobrazowane zostaną problemy w nazewnictwie poszczególnych elementów opraw, jakich może nastręczać różnorodność rozwiązań stosowanych przez introligatorów. Problem ten dotyczy wielu terminów introligatorskich, jednakże w niniejszym tekście ograniczę się jedynie do zasygnalizowania kwestii związanych z nazewnictwem elementów zwanych w polskiej literaturze kartami przybyszowymi. Złożoność problemu nie pozwala na przedstawienie w ramach jednego artykułu wszystkich możliwych rozwiązań i konstrukcji kart przybyszowych w oprawie. Nie sprzyja temu również ograniczenie czasowe i terytorialne zaprezentowanych przykładów. Toteż celem artykułu

4 J. Szirmai, The Archeology of Medieval Bookbinding, Ashgate 2000, s. 178; E. Chlebus, Technika wykonania opraw jako przedmiot badań tegumentologicznych, [w:] Tegumentologia polska dzisiaj, pod red. A. Wagnera, Toruń 2015, s. 365-390.

${ }^{5}$ Ma to istotne znaczenie dla tegumentologów, gdyż analiza techniki wykonania może stanowić użyteczne narzędzie identyfikacji opraw. Por. E. Chlebus, op. cit.

${ }^{6}$ Postulat uporządkowania polskiej terminologii oprawoznawczej wysuwany był wielokrotnie. Por. m.in. A. Birkenmajer, W sprawie rejestracji i katalogowania opraw zabytkowych, [w:] Studia bibliologiczne, pod red. H. Więckowskiej, A. Birkenmajera, Wrocław 1975, s. 177-178; E. Pokorzyńska, O potrzebie słownika oprawoznawczego, [w:] Tegumentologia polska dzisiaj..., s. 57-77.

${ }^{7}$ Encyklopedia wiedzy o książce, pod red. A. Birkenmajera, Wrocław 1971 (dalej: EWoK). 
jest raczej ukazanie różnorodności stosowanych rozwiązań i uwypuklenie takich przypadków, które podważają przyjęte definicje lub przynajmniej skłaniają do powtórnego przyjrzenia się definicjom poszczególnych elementów wchodzących w skład kart przybyszowych.

Spróbujmy najpierw uporządkować istniejące terminy. Jak już wspomniałam, określenie „karty przybyszowe” oznacza karty dodane przez introligatora do bloku podczas oprawiania książki. W języku niemieckim odpowiada mu z grubsza termin Vorsatz ${ }^{8}$, a w języku angielskim endleaves ${ }^{9}$, względnie endpapers, czyli karty znajdujące się na początku i końcu bloku książki. Zgodnie z wskazaną wyżej definicją termin „karty przybyszowe” obejmuje zarówno wyklejki, jak i tzw. karty ochronne dodane na początku i końcu tekstu, ale także np. interfolia wstawiane przez introligatora pomiędzy kartami tekstu. Zwykle jednak termin ten używany jest w odniesieniu do kart dodanych na początku i końcu bloku. W przeciwieństwie do określenia „karty przybyszowe”, zarówno niemiecki termin Vorsatz, jak i angielskie endleaves, czyli karty końcowe, etymologicznie nie wskazują na pochodzenie tych arkuszy, a jedynie na ich lokalizację. Obu tych terminów używa się jednak najczęściej w podobnym znaczeniu, jak określenia „karty przybyszowe" - wyłącznie w odniesieniu do kart dodanych na początku i końcu bloku. Nie każda jednak wyklejka i nie każda czysta karta na początku lub końcu książki jest kartą przybyszową. Introligatorzy często, zamiast dodawać do bloku dodatkowe arkusze, wykorzystywali przy oprawie czyste, niezadrukowane (a w przypadku rękopisów - niezapisane) karty bloku (ang. blank textleaf, text blank). W skrajnych przypadkach jako wyklejkę stosowano nawet przyklejoną do okładziny kartę tytułową druku (il. 1). W języku angielskim takie zaadaptowane przez introligatora karty druku nazywa się integral endleaves ${ }^{10}$, a mianem separate endleaves ${ }^{11}$ określa się karty końcowe dodane osobno przez introligatora (czyli de facto karty przybyszowe).

W szerszym sensie do kart przybyszowych zaliczyć można wykonane z papieru lub pergaminu elementy konstrukcyjne wspomagające szycie i zawieszenie bloku, jak np. scyzury, zszywki czy wyklejenie grzbietu. Dla tak szerokiego rozumienia terminu „karty przybyszowe”, obejmującego zarówno pełne karty, jak i fragmenty kart, analogie znajdujemy również w innych językach. Angielski

8 „Vorsatz oder Vorsetz ist die buchbinderische Bezeichnung für die dem Buch vor- und nachgehefteten Blätter, die nicht zu den Druckbogen gehören. Sie dienen zum Schutze (franz.: gardes) der ersten und letzten Blätter des Buches und der Verbindung des Buchblocks mit den Deckeln, ferner zur inneren Bekleidung der Deckel [...]", za: Lexikon des Gesamten Buchwesens, t. 3, pod red. K. Löfflera, J. Kirchnera, Leipzig 1937, s. 538.

9 „Endleaves are all the groups of leaves of a variety of sheet materials found at each side of a bookblock and are intended to give protection to the text leaves", za: The Language of Bindings Thesaurus (dalej: LoB), http://www.ligatus.org.uk/lob/concept/1317 [dostęp: 31.08.2017].

${ }^{10}$ LoB, http://www.ligatus.org.uk/lob/concept/1398 [dostęp: 31.08.2017].

11 LoB, http://www.ligatus.org.uk/lob/concept/1573 [dostęp: 31.08.2017]. 


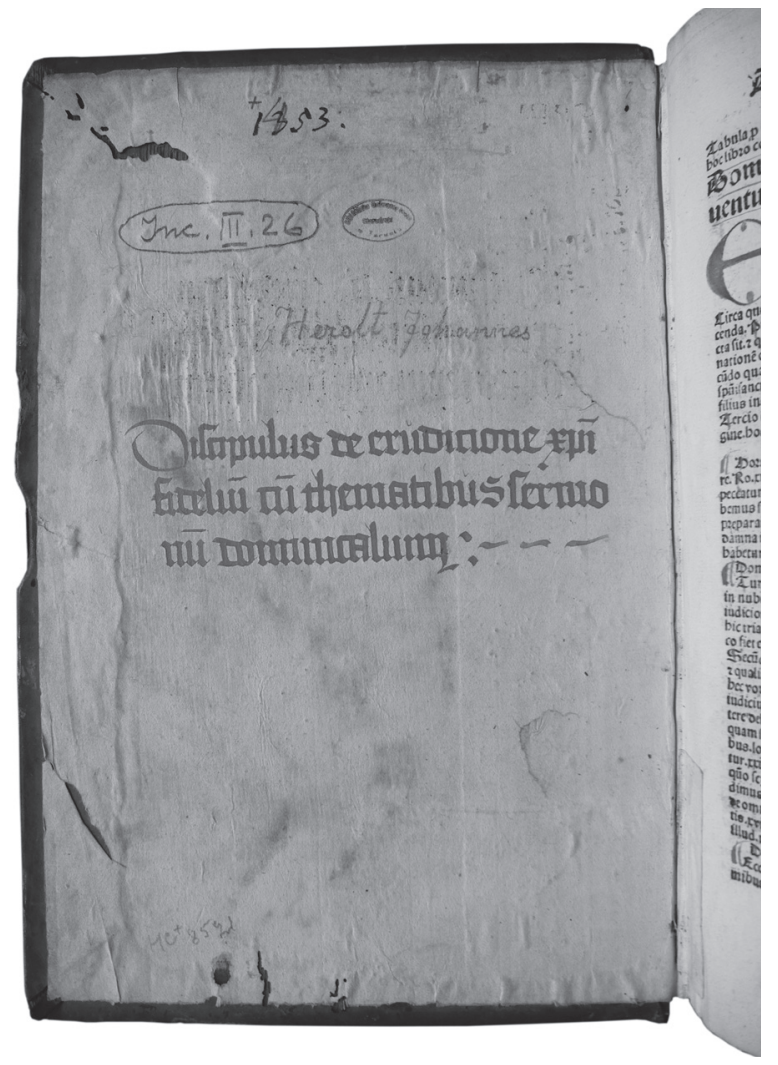

I1. 1. Karta tytułowa inkunabułu zaadoptowana jako wyklejka. Tytuł druku wypisany odręcznie przez introligatora na stronie verso. Ioannes Herolt, Liber discipuli de eruditione Christifidelium, Strassbourg, Io. Prüss, 1490. Ze zbiorów Biblioteki UMK, sygn. Inc.III.26

słownik Language of Bindings pod hasłem endleaf components ${ }^{12}$ ujmuje również scyzurę, czyli endleaf guard. Odnośnie do określenia Vorsatz Birkenmajer zauważa, że w niemieckim dyskursie termin ten oznacza „,nie tylko 'wyklejkę' w potocznym słowa znaczeniu, ale również 'karty ochronne' i 'falce"”'13. Pewnym nadużyciem może się wydawać włączenie do tej grupy również pergaminowych pasków wyklejających grzbiet, jednakże, jak pokażę dalej, elementy te mogły pełnić również funkcję scyzur. Właściwie w przypadku scyzur, zszywek czy wyklejenia grzbietu należałoby mówić raczej nie o kartach, lecz o elementach przybyszowych. Potrzeba ustanowienia szerszego terminu jest tu całkowicie zrozumiała i uwarunkowana względami praktycznymi. Introligator dodawał do bloku cały pakiet elementów, w których obok kart znajdowały się również mniejsze

12 LoB, http://www.ligatus.org.uk/lob/concept/2886 [dostęp: 11.12.2017].

13 A. Birkenmajer, op. cit., s. 179, przyp. 40. 
komponenty (scyzury, zszywki). Przy opisie techniki wykonania oprawy muszą one być traktowane łącznie z wyklejkami i kartami ochronnymi. Ponadto w przypadku opraw późnogotyckich wymienione elementy konstrukcyjne wykonywano zwykle z pergaminu, często z tego samego, który stosowano na karty ochronne lub wyklejki.

Wyklejka (niem. geklebte Vorsatzblatt, Spiegel, ang. pastedown) to arkusz papieru lub pergaminu, który — jak wskazuje nazwa — wykleja wewnętrzną stronę okładziny. Definicja podawana przez $\mathrm{EWoK}^{14}$ ukuta jest w odniesieniu do książek współczesnych i jest nieadekwatna dla opraw gotyckich, w których element ten przyjmował bardzo różne formy. Podkreślić należy, że wyklejka nie jest elementem niezbędnym, obecnym w każdej książce. Wiele opraw gotyckich nie miało wyklejek, a zaopatrzone były jedynie w karty ochronne. Pierwotny brak wyklejek warto odnotować w opisie oprawy, jednakże należy tu zachować szczególną ostrożność, gdyż czasem trudno jest ocenić, czy oprawa rzeczywiście nie miała wyklejek, czy też zostały one wymontowane, np. przez badaczy makulatury ${ }^{15}$. Czasem również coś, co na pierwszy rzut okaz wygląda jak karta ochronna, jest $\mathrm{w}$ istocie wyklejką, która odkleiła się od okładziny w wyniku działania wilgoci.

Wyklejki stanowiły przede wszystkim estetyczne wykończenie książki, zasłaniając i izolując podwinięcia skóry oraz miejsca mocowania zwięzów i okuć do okładzin, jednakże w zależności od formy i konstrukcji mogły również pełnić różne dodatkowe funkcje. Wyklejka, zwłaszcza pergaminowa, stanowić mogła wzmocnienie zawieszenia książki. Jeśli była doszywana do bloku, wzmacniała przeguby, przejmując część naprężeń powstających przy otwieraniu książki ${ }^{16}$. W zależności od zastosowanej konstrukcji wyklejka mogła także zasłaniać szczelinę pomiędzy blokiem a okładziną.

Jako wyklejki często używano makulatury o różnym formacie, nie zawsze odpowiadającym wymiarom bloku (il. 2). Czasem sklejano je z kilku mniejszych kart papieru lub pergaminu. Wyklejki mogły być dołączone przez introligatora na różnym etapie oprawy książki — w trakcie szycia, przed lub po oklejeniu okładzin skórą. W pierwszym przypadku wyklejki mogły zostać doszyte jako pojedyncze

14 „Wyklejka (potocznie zwana przez drukarzy również forzacem), dwukartkowa składka przyklejona lub przyszywana do pierwszego i ostatniego arkusza książki w oprawie twardej. Zadaniem wyklejki jest ochrona przed zniszczeniem zewnętrznych arkuszy książki i związanie bloku książkowego z okładką, często też wewnętrzne przyozdobienie ścianek okładki. Zewnętrzną stroną jednej kartki jest wyklejka przyklejona w całości do wewnętrznej ścianki okładki, druga kartka przyklejona jest tylko brzegiem wzdłuż załamów do pierwszego i ostatniego arkusza" EWoK, szp. 2550.

${ }^{15} \mathrm{O}$ pierwotnej obecności wyklejek wnioskować możemy na podstawie śladów kleju czy odbić atramentu lub druku na deskach.

16 Przy wyklejkach złożonych z pojedynczego arkusza zawieszenie książki opierało się na zwięzach, skórze oklejającej okładziny i grzbiet, ewentualnie część naprężeń przejmowała scyzura oraz pergaminowe paski wklejane na grzbiecie. 


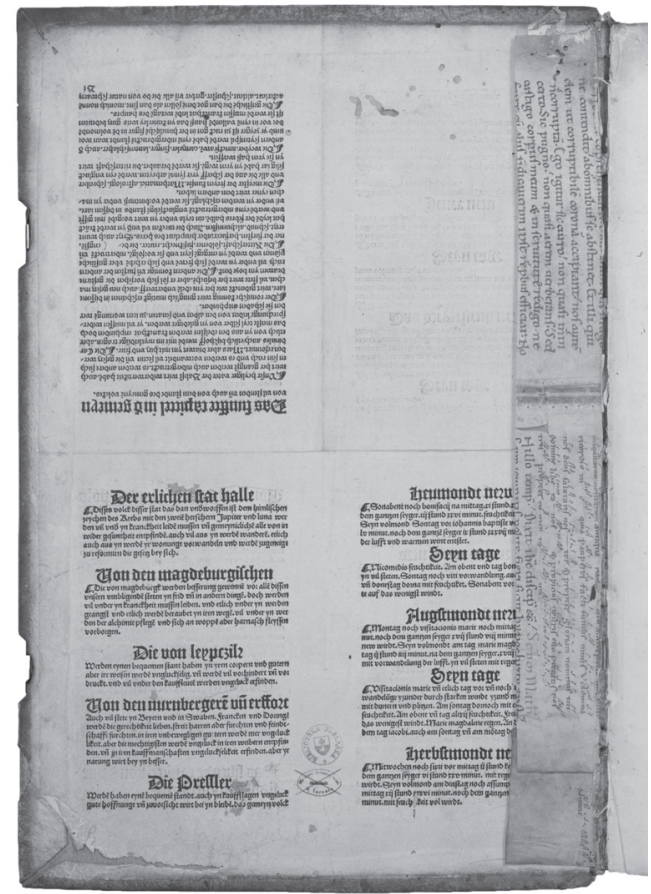

Il. 2. Wyklejka wykonana z nierozciętego arkusza drukowanej makulatury o mniejszym formacie. Nicolaus Falcutius, Sermones medicinales. P. V-VI, Venezia, Bern. Stagninus, 1491.

Ze zbiorów Biblioteki Elbląskiej, sygn. Inc.IV.24. Fot. E. Chlebus

karty (z falcem/zagiętka/piętka — niem. Falz, ang. stub) (il. 3.h), w składce z kartami ochronnymi (il. 3.d) lub razem ze składkami bloku (il. 3.e). W oprawach późnogotyckich bardzo często stosowany był inny typ wyklejki — niezależne od bloku pojedyncze karty (il. 3.g). W większości przypadków karty te przyklejane były do okładzin po naklejeniu skóry, choć zdarzają się przypadki, w których wyklejki przykryte zostały podwinięciami obleczenia (il. 4). Frapujący jest przykład przedstawiony na ilustracji $5^{17}$. Okładziny zostały najpierw oklejone kartami pergaminowej makulatury, a dopiero potem połączone z blokiem poprzez przewleczenie zwięzów i rdzeni kapitałek przez otwory w desce. Ponieważ kartę przyklejono przed połączeniem okładzin z oprawą, skórzane rdzenie kapitałek przewleczone zostały poprzez nią. Czy stanowi ona zatem wyklejkę wklejoną pod podwinięciami skóry, czy też raczej wyklejenie (wzmocnienie) okładzin? Równie problematyczny przykład stanowi doszyte do bloku pergaminowe bifolium, którego jedną kartę doklejono do okładzin przed przyklejeniem skóry, a drugą -

17 Za wskazanie mi tego przykładu serdecznie dziękuję Urszuli Wenckiej, konserwatorce książki z Zakładu Narodowego im. Ossolińskich we Wrocławiu. 

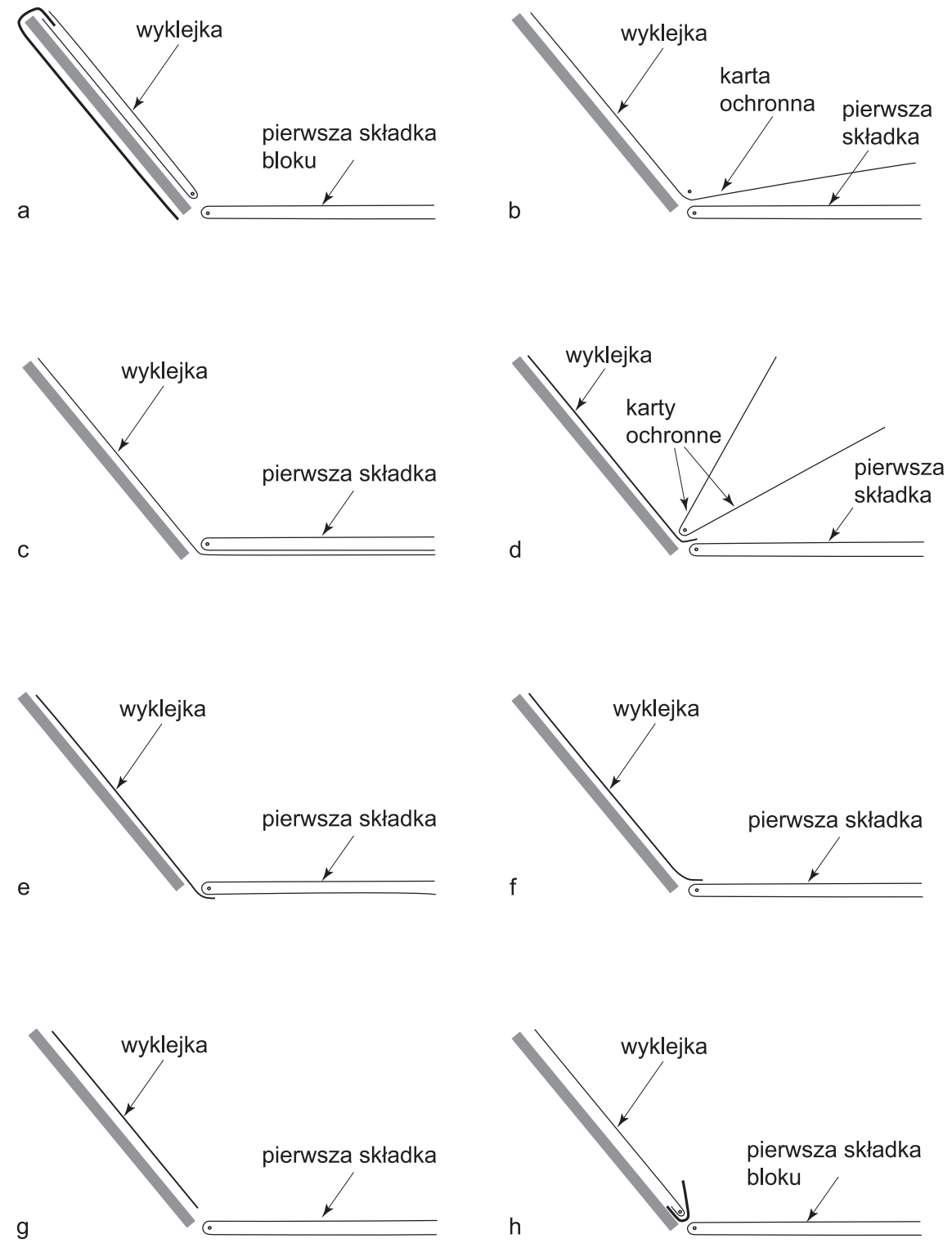

Il. 3. Schematy przedstawiające przykładowe układy wyklejek w oprawach gotyckich. Opracowanie własne

po wykonaniu podwinięć skóry (il. 3.a). Ponieważ okładzina w tym przypadku wykonana została ze sklejonych z sobą arkuszy makulatury, pojawia się pytanie, czy przyklejoną pod podwinięcia kartę tego bifolium uznać za jedną z warstw wyklejki, czy też za wyklejenie okładzin, względnie za część okładziny. Wydaje się, że w tych przypadkach można postulować rozstrzygnięcie odnoszące się do kolej- 


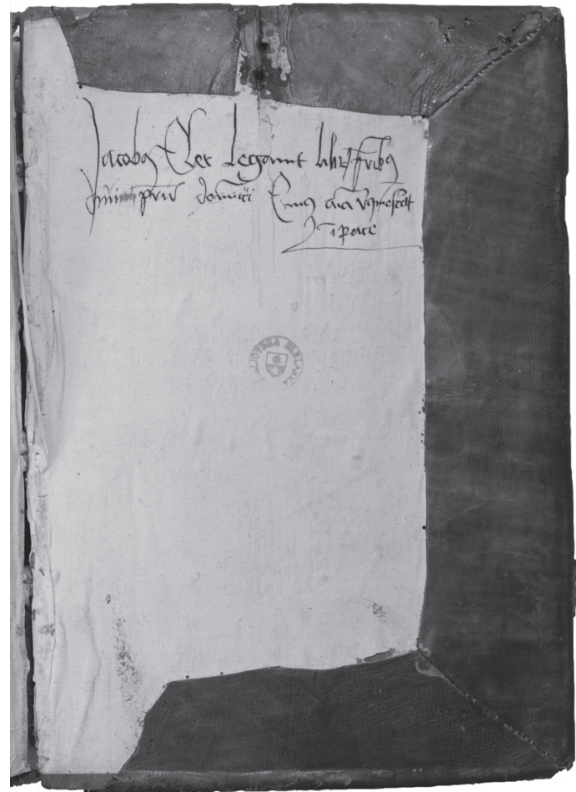

Il. 4. Wyklejka wklejona pod podwinięcia skóry. Bernardus Claravallensis, Sermones de tempore et de sanctis et de diversis,

[Speyer], [Petr. Drach], 1481/82. Ze zbiorów Biblioteki Elbląskiej, sygn. Inc.III.51.

Fot. E. Chlebus

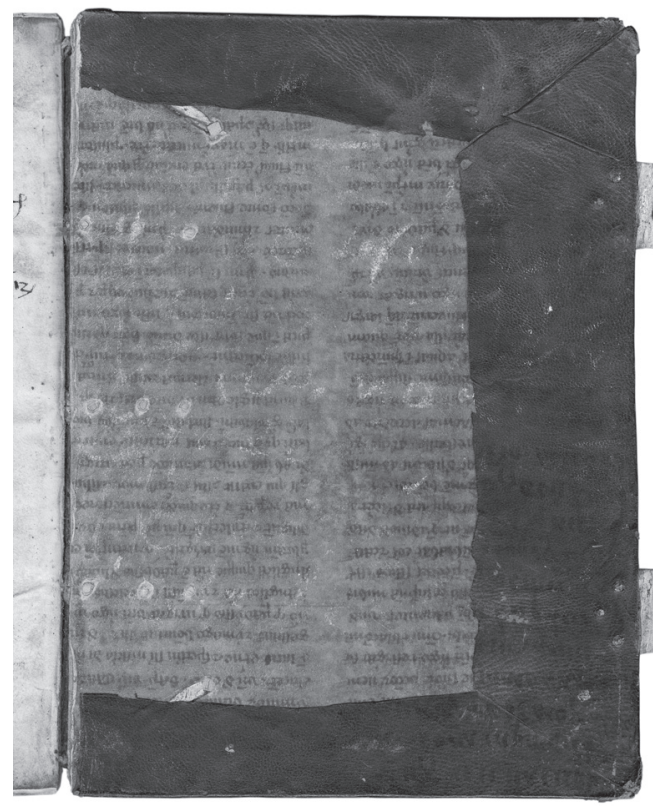

I1. 5. Karta pergaminu przyklejona do okładziny przed jej połączeniem z oprawą. Widoczne przewleczone przez nią rdzenie kapitałek oraz rzędy drewnianych kołeczków mocujące zwięzy. Michael de Carcano, Sermonarium de poenitentia per adventum et quadragesimam, Venezia, Georg. Arrivabene 1496. Ze zbiorów Biblioteki ZNiO we Wrocławiu, sygn. XV-99

ności prac introligatora. Jeśli dany element przyklejony został do okładziny przed jej połączeniem z oprawą, proponuję nazywać go wyklejeniem okładziny, jeśli zaś przyklejony został po przewleczeniu zwięzów przez otwory w okładzinach, względnie po przyklejeniu zwięzów do okładzin — możemy mówić o wyklejce.

Poza wyklejką dalsze karty dodane przez introligatora na początku lub końcu bloku określa się mianem kart ochronnych (niem. fliegende Blatt, ang. flyleaf). Ich celem była — jak wskazuje nazwa — ochrona krańcowych kart tekstu. Doszywano je w różnej liczbie, nie zawsze jednakowej, po obu stronach bloku. Czasem część z nich stanowiły karty papierowe, a część pergaminowe. Podobnie jak wyklejki, karty ochronne wykonywane były w II połowie XV i na początku XVI wieku z czystych arkuszy papieru bądź pergaminu lub z rękopiśmiennej czy drukowanej makulatury. Karta ochronna może tworzyć wraz z wyklejką jeden arkusz (bifolium) (il. 6.a, b), który często w całości określany jest jako wyklejka. Dla większej precyzji proponuję jednak nazywać go arkuszem wyklejkowym złożonym z wyklejki i karty ochronnej. W omawianym okresie nie jest to jednak najpopularniejsze rozwiązanie. Złożona z wąskim falcem karta ochronna mogła być 
a

\section{wyklejka}
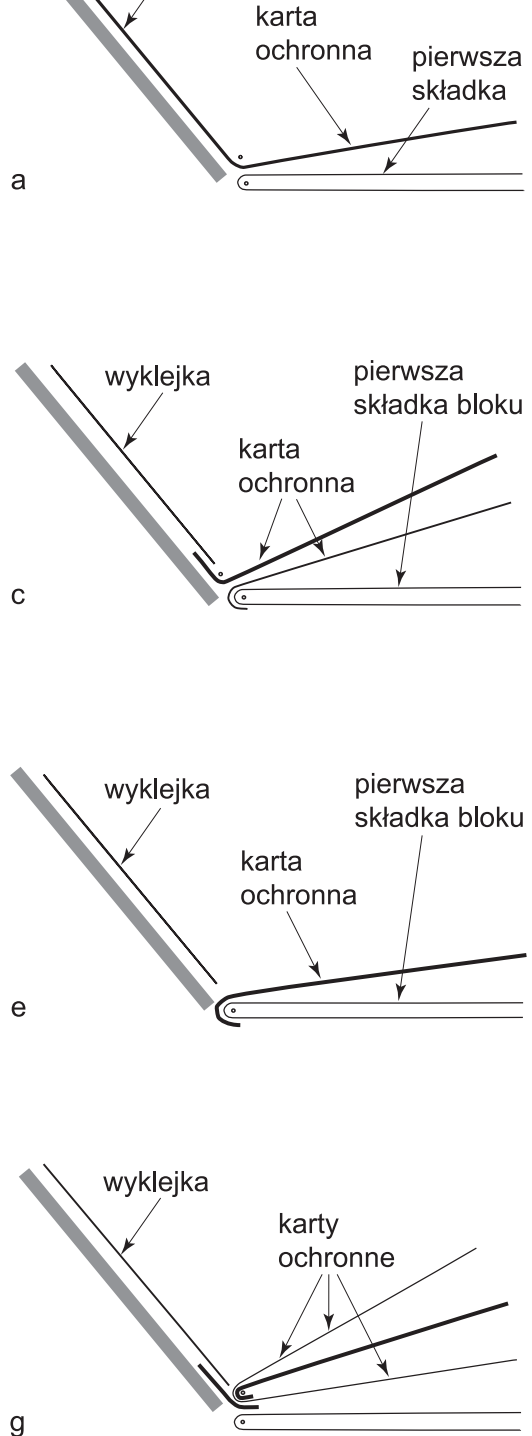

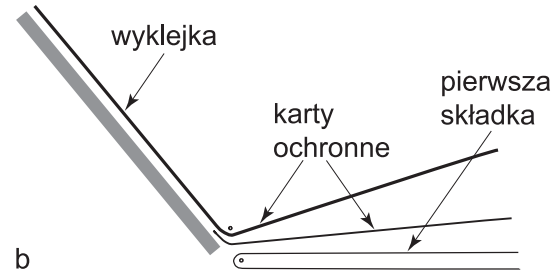

d
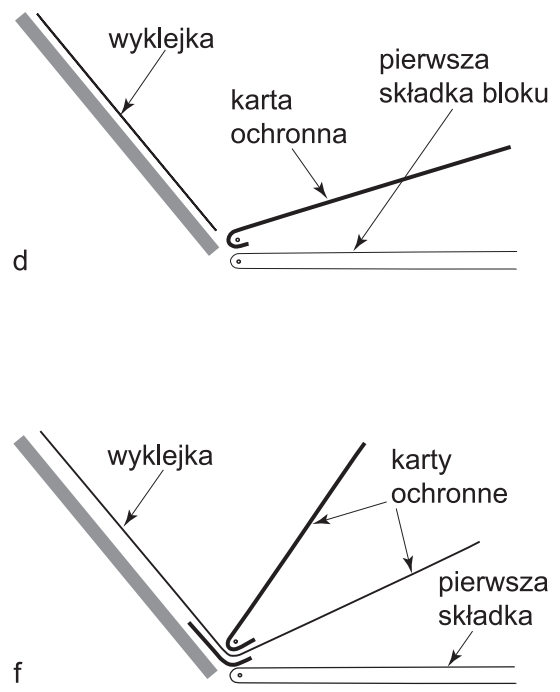

$\mathrm{h}$

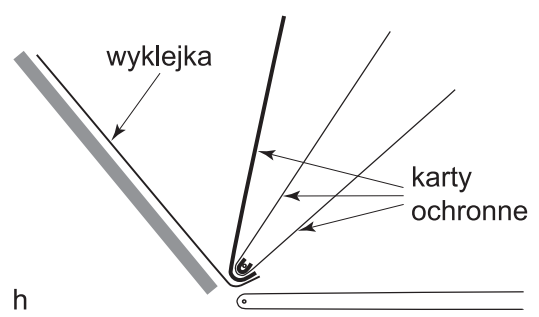

Il. 6. Schematy przedstawiające przykładowe układy kart ochronnych w oprawach gotyckich. Pogrubioną linią oznaczono pergamin. Opracowanie własne

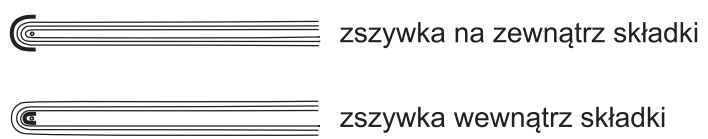

Il. 7. Schematy przedstawiające zszywki w oprawach gotyckich. Pogrubioną linią oznaczono pergamin. Opracowanie własne 

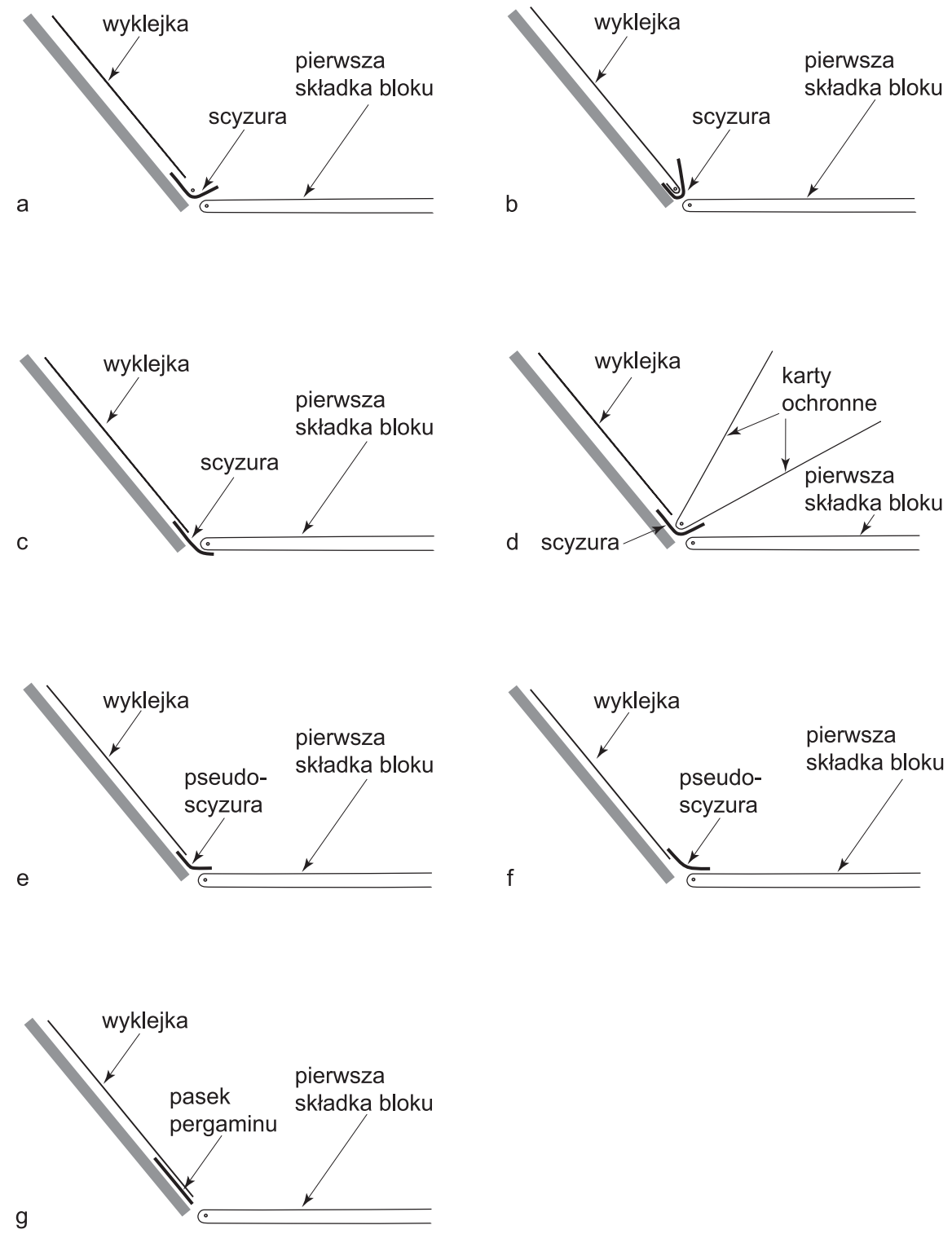

I1. 8. Schematy przedstawiające przykładowe układy scyzur i zbliżonych elementów.

Pogrubioną linią oznaczono pergamin. Opracowanie własne

doszyta do bloku niezależnie od wyklejki czy składek tekstu (il. 6.d), mogła też o nie zahaczać (il. 6.e). I wreszcie dodane przez introligatora karty mogły tworzyć osobne, autonomiczne względem bloku i wyklejki składki (il. 6.g). EWoK proponuje następujące rozróżnienie ${ }^{18}$ : jeżeli karty ochronne tworzą osobną składkę na

18 EWoK, szp. 2634-2635. 
początku lub końcu bloku, określa się je odpowiednio jako antefolia i postfolia; jeśli zaś założone są za pierwszą i ostatnią składkę — określane są jako zszywki lub przyszywki. To rozróżnienie nie było jednak powszechnie przyjęte. W przypisie jednej z prac Aleksandra Birkenmajera znajdujemy następujące wyjaśnienie: „Za przewodem p. kol. K. Piekarskiego nazywam zszywką taką kartę przybyszową, która w jakikolwiek sposób uczestniczyła w powstawaniu bloku książkowego w chwili jego zszywania. Zszywkami są więc tak zwane przez niemieckich (i naszych!) introligatorów Vorsatz' $e^{\text {"19. }}$. Według tej definicji zszywkami są zatem także ante- i postfolia. W innym miejscu Birkenmajer, również powołując się na terminologię stosowaną przez Kazimierza Piekarskiego, doszytą do bloku dwukartkową składkę przeszytą w środku nazywa przyszywką i tłumaczy:

Wprowadzamy tu nowotwór terminologiczny celem (częściowego) uzgodnienia naszego słownictwa z tym, jakiego od lat używa dr Kazimierz Piekarski. Za jego przewodem rezerwujemy mianowicie termin „zszywka” dla tego rodzaju introligatorskich kart przybyszowych, które są „założone” za pierwszą i ostatnią składkę bloku (trzonu) książki i razem z nią przyszyte do wiązadeł. „Zszywki” są powszechnym zjawiskiem w dzisiejszym introligatorstwie; w oprawie Psalterza floriańskiego nie występują. Nasze „przyszywki” są natomiast przyszyte do wiązadeł niezależnie od składek trzonu. W takim przypadku dr Piekarski używa słów „,antefolium” i ,postfolium”. Wydaje się nam jednak (i jesteśmy tu w zgodzie z praktyką stosowaną przy katalogowaniu rękopisów), że dogodniej jest te ostatnie nazwy uniezależnić od takiego czy innego postępowania introligatora i używać ich raczej w związku z funkcją ochraniania, jaką pewne (najczęściej czyste) karty spełniają w stosunku do pierwszej i ostatniej zapisanej (zadrukowanej) karty książki. A więc antefolia są to przednie karty ochronne, postfolia tylne karty ochronne rękopisu (druku, klocka), niezależnie od tego, czy ze stanowiska introligatora są to „zszywki”, ,przyszywki” czy nawet karty od początku należące do pierwotnego trzonu rękopisu (w przypadku, kiedy pisarz rozpoczął np. swoją pracę dopiero na drugiej karcie pierwszej składki) [...]. Rozumie się przy tym, że do istoty antefolium (postfolium) należy, ażeby to nie była karta nalepiona na okładkę ${ }^{20}$.

Zaproponowane przez Birkenmajera rozumienie terminów „,antefolia” i „postfolia", jako przednich i tylnych kart ochronnych, wydaje się sensowne. Terminy „zszywki” i „przyszywki” są jednak wieloznaczne i mylące. Tym bardziej że zszywkami przyjęło się również nazywać wąskie paski pergaminu wzmacniające grzbiety lub wewnętrzne części składek. Ze względu na wieloznaczność terminu „Zszywki” proponuję ograniczyć jego stosowanie wyłącznie do tego znaczenia.

Zszywki (zwane czasem zagiętkami, niem. Heftfältzchien, ang. stays lub sewing guards), czyli wąskie paski pergaminu wzmacniające papierowe karty i chroniące je przed uszkodzeniem przez nić szycia, dodawano od zewnętrznej lub od wewnętrznej strony składki (il. 7). Miały one zastosowanie zwłaszcza w książkach zszywanych systemem zintegrowanym, gdzie nić nie przechodziła ze składki do składki w plątniku, lecz biegła aż do zwięzu kapitałkowego u szczytu i podstawy

19 A. Birkenmajer, Oprawa rękopisu 2470 Biblioteki Jagiellońskiej i inne oprawy tej samej pracowni introligatorskiej, [w:] Studia bibliologiczne..., s. 224, przyp. 164.

20 A. Birkenmajer, Obecna oprawa Psalterza floriańskiego, [w:] Studia bibliologiczne..., s. 82 , przyp. 6 .

Roczniki Biblioteczne 61, 2017

(C) for this edition by CNS 

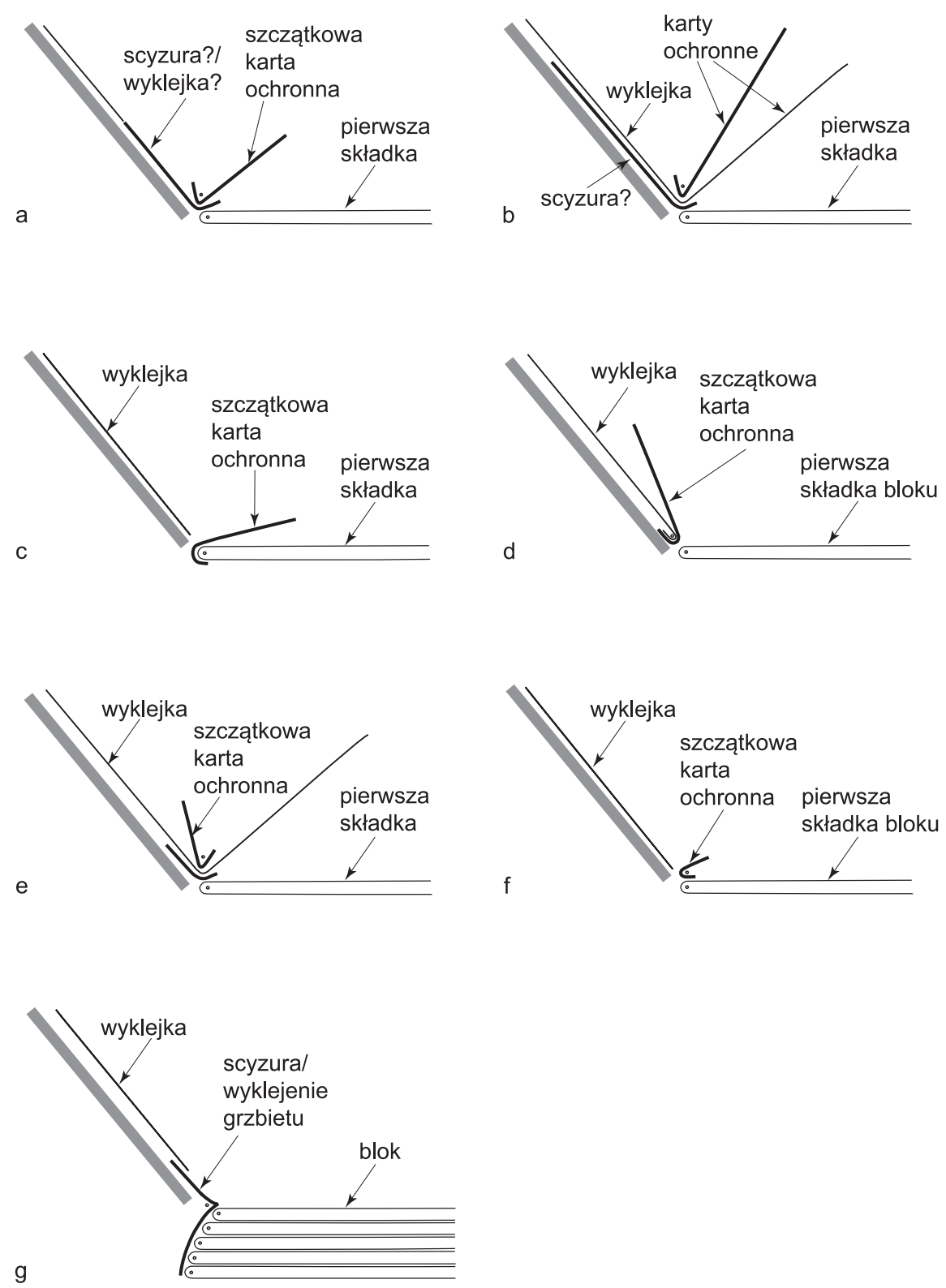

I1. 9. Schematy przedstawiające trudne do zdefiniowania elementy opraw gotyckich. Pogrubioną linią oznaczono pergamin. Opracowanie własne

grzbietu. Zszywki można uznać za zredukowaną postać tzw. składek mieszanych, czyli spotykanego w tradycji rękopiśmiennej rozwiązania, w którym zewnętrzne i/lub wewnętrzne karty każdej składki wykonane były z pergaminu, a pozostałe 


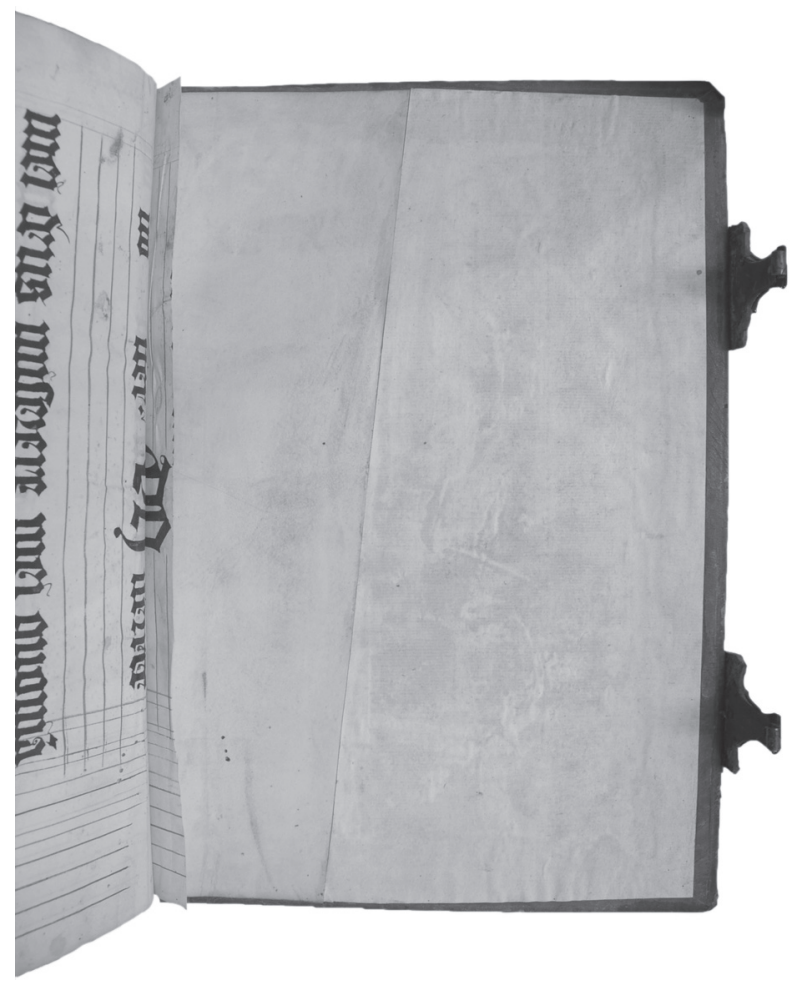

Il. 10. Scyzura?/Wyklejka wykonana w połowie z pergaminu, a w połowie z papieru. Alfonso de Montalvo Diaz, Repertorium quaestionum super Nicolaum de Tudeschis, Basel, Ioannes Amerbach, ca 1487/88. Ze zbiorów Biblioteki "Hosianum” w Olsztynie, Inc.155. Fot. E. Chlebus

— z papieru ${ }^{21}$. Choć zszywki pojawiały się częściej w oprawach rękopisów spisanych na papierze, są również spotykane w inkunabułach. W drukach najczęśsciej wzmacniały wyłącznie jedną lub dwie pierwsze i ostatnie składki w bloku. Pergaminowe paski były zwykle nieco krótsze niż wysokość bloku. Spotykane są również zszywki nieciągłe (separate sewing guards ${ }^{22}$ ) — osobne paseczki pergaminu odpowiadające poszczególnym stacjom szycia.

Najtrudniej uchwytnym terminem jest scyzura, zwana również scezurą lub falcem wyklejkowym (niem. Ansetzfalz, ang. strenghtener, guard ${ }^{23}$ ). Jest to pergaminowy ${ }^{24}$ pasek wzmacniający zawieszenie bloku w oprawie. Scyzura przej-

${ }^{21}$ Por. Jak czytać rękopis średniowieczny, pod red. P. Géhin, Warszawa 2008, s. 61. O takich konstrukcjach wspomina m.in. J. Szirmai, op. cit., s. 176.

${ }^{22}$ LoB, http://www.ligatus.org.uk/lob/concept/4921 [dostęp: 31.08.2017].

23 Angielski termin guard ma bardzo szerokie znaczenie i obejmuje wszelkie węższe lub szersze paski pergaminu wszyte do bloku, a zatem zarówno scyzury, jak i zszywki.

24 W przypadku późniejszych opraw również papierowy lub płócienny. 


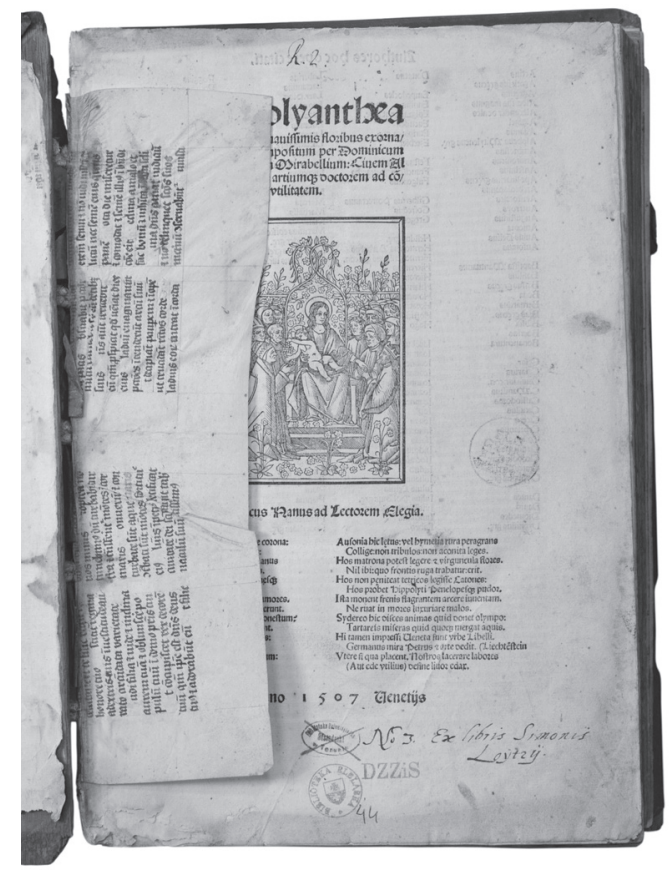

I1. 11. Szczątkowa karta ochronna. Współoprawne druki: Dominicus Nanus Mirabellius, Polyanthea Opus suauissimis floribus..., Venetiis, Petri Liechtenstein Coloniensis Gremani, 1507 oraz Hieronymus, Commentaria in Bibliam, Venetiis, Johannem \& Gregorium de Gregoriis, 1498. Ze zbiorów Biblioteki Elbląskiej, sygn. Inc.III.114-115. Fot. E. Chlebus

muje część naprężeń powstających w przegubie przy otwieraniu książki. Bez niej skupiałyby się one na zwięzach oraz na skórze pokrywającej oprawę. Jednakże oprócz wzmacniania zawieszenia książki scyzura pełni szereg innych dodatkowych funkcji. Doszyta wraz z arkuszem wyklejkowym lub kartami ochronnymi, wzmacnia grzbiet tych kart i chroni go przed przedarciem, jest więc zarazem zszywką wyklejki lub kart ochronnych. Scyzura może pełnić również funkcje estetyczne. Zasłania ona szczelinę, jaka pojawia się w wielu oprawach gotyckich pomiędzy wyklejką a blokiem książki. Jeśli scyzura jest odpowiednio szeroka, może również maskować rynienki, w których zakołkowane są zwięzy w okładzinach, tak by nierówności nie uwidoczniały się pod wyklejką ${ }^{25}$.

Problem pojawia się, gdy chcemy zdefiniować jasno, co jest scyzurą, a co nią nie jest. Czy scyzurą jest pergaminowy pasek zaklejający szczelinę pomiędzy okładziną a blokiem (il. 8.e, f), którego funkcja jest już raczej estetyczna, a w mniejszym stopniu konstrukcyjna (nie jest doszyty do bloku)? Czy scyzurą

${ }^{25}$ Funkcję maskowania połączenia pomiędzy blokiem a oprawą pełnić może również pasek pergaminu niepełniący żadnych funkcji konstrukcyjnych w oprawie. Por. il. 8.g. 


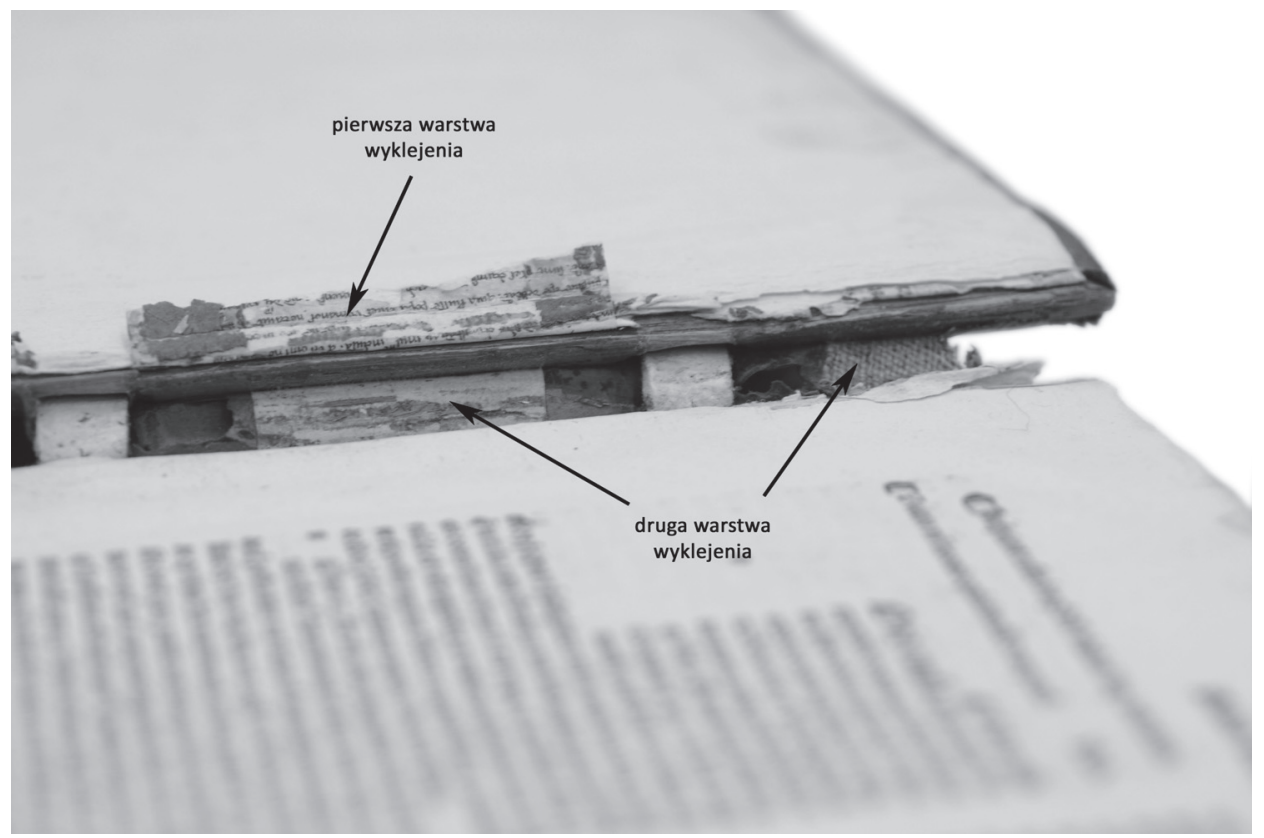

I1. 12. Dwuwarstwowe wyklejenie grzbietu. Warstwę zewnętrzną tworzą paski pergaminu oraz płótna. Współoprawne druki: Vivianus Tuscus, Casus longi super Infortiato, Lyon, Ioannes Siber, ca 1490 oraz Franciscus Accursius, Casus longi super Digesto novo, Lyon, Ioannes Siber, 1498. Ze zbiorów Biblioteki "Hosianum" w Olsztynie, sygn. Inc.198. Fot. E. Chlebus

jest zszywka chroniąca grzbiet wyklejki z falcem podwiniętym pod siebie (il. 8.b), czy też scyzura powinna jednym końcem zahaczać o pierwszą składkę bloku lub karty ochronne (il. 8.c, d)? Proponuję, aby za właściwą scyzurę uznać jedynie taki element, który jest połączony z blokiem za pomocą szycia (bez względu na to, czy jest założony za pierwszą/ostatnią składkę czy nie), a z okładziną poprzez przyklejenie do jej wewnętrznej strony. Pasek pergaminu wklejony od wewnątrz w przegubie, lecz niedoszyty do bloku, określić można jako pseudoscyzurę.

Trudność w nazewnictwie stwarzają elementy pewnej osobliwej konstrukcji (i1. 9.a, 10), w której dwie niepełne pergaminowe karty złożone są falcami do wewnątrz i razem przyszyte, przy czym jedna z kart wykleja okładzinę mniej więcej do połowy jej szerokości, a pozostała część deski wyklejona jest papierem. Pergaminowa część tej konstrukcji przyklejona do okładziny mieści się w definicji scyzury, nie jest jednak przykryta wyklejką, jak w przypadku innej, bardzo szerokiej scyzury przedstawionej na ilustracji 9.b. Można więc tutaj mówić zarówno o scyzurze, jak i o wyklejce złożonej w połowie z papieru, a w połowie z pergaminu.

Próbom terminologicznego ujęcia wymykają się również różnorodne formy pośrednie, np. paski pergaminu o szerokości $1 \frac{1}{2}$ strony, będące czymś pomię- 


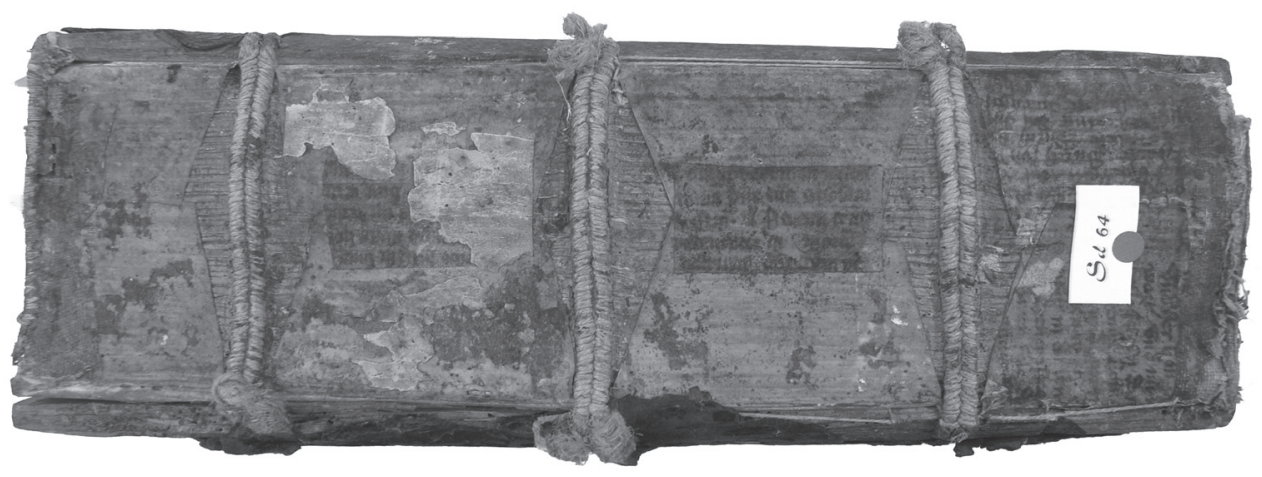

Il. 13. Wyklejenie grzebieniowe. Paski obu scyzur zachodzą na siebie na grzbiecie. Dodatkowo miejsce połączenia wzmocniono prostokątnymi fragmentami pergaminu. Współoprawne druki:

Baptista Trovamala, Summa Rosellae de casibus conscientiae, Strasbourg, Johann Knobloch,

1516 oraz Dominicus Nanni, Polyanthea, Basel, Adam Petri, 1512. Ze zbiorów Biblioteki "Hosianum" w Olsztynie, sygn. Sd 64. Fot. E. Chlebus

dzy kartą ochronną z falcem założonym za grzbiet składki a wąskim paskiem wzmacniającym grzbiet składki (il. 9.c, 11). Element ten można by nazwać zarówno zszywką, jak i szczątkową kartą ochronną, ewentualnie półkartą/ćwierćkartą ochronną. Analogicznie można nazwać podobny szeroki element wzmacniający grzbiet wyklejki, który w zasadzie pasuje do definicji scyzury (il. 9.d). Szczątkową kartą ochronną jest też właściwie pergaminowy element wzmacniający od wewnątrz arkusz złożony z wyklejki i karty ochronnej, przedstawiony na il. 9.e, a także niezależny od bloku i wyklejki pasek nieprzyklejony do okładziny (il. 9.f).

Kolejnym elementem przybyszowym, wykonywanym najczęściej z pergaminowej makulatury, jest wyklejenie grzbietu (ang. spine lining) ${ }^{26}$. Wyklejenie utrzymywało spoistość bloku w grzbiecie i zwykle wspomagało również zawieszenie bloku. W oprawach późnogotyckich wyklejenie miało najczęściej formę pergaminowych pasków przyklejanych do grzbietu pomiędzy zwięzami. Paski te mogły mieć różną szerokość — od bardzo wąskich po wypełniające w całości międzyzwięźla. Zwykle były one dłuższe od szerokości grzbietu, a fragmenty wychodzące poza grzbiet doklejano od zewnętrznej lub od wewnętrznej strony okładziny. Czasem paski nacinano, przyklejając ich połowę od strony wewnętrznej, a połowę od zewnętrznej ${ }^{27}$. U szczytu i podstawy grzbietu wyklejenie stanowiło często zarazem podkładkę kapitałki, a po złożeniu mogło nawet ją imitować. Spotykane jest również dwuwarstwowe wyklejenie grzbietu. W jednym z wariantów, przedstawionym na il. 12, pierwszą warstwę stanowiły paski, których przedłużenia przyklejano do wewnętrznej strony okładziny, a przedłużenia pasków z drugiej warstwy (część z nich wykonano z pergaminu, a część z płótna) przyklejano

${ }^{26}$ Obok pergaminu do wyklejenia grzbietu stosowano również papier, skórę i płótno.

27 Por. J. Szirmai, op. cit., s. 195. 
od strony zewnętrznej. Wyklejenie grzbietu, podobnie jak scyzura, nie było stosowane we wszystkich oprawach. Nie zawsze również da się bez demontażu oprawy ocenić, czy element ten jest obecny. Wyklejenie w postaci pasków krótszych od szerokości grzbietu nie uwidacznia się w przegubie, więc w przypadku dobrze zachowanych opraw pozostaje nierozpoznane.

Próbom jednoznacznego zdefiniowania wymyka się pergaminowy element przedstawiony na schemacie 9.g. Złożony na pół pergaminowy pasek doszyto do bloku, a następnie jedną jego część przyklejono do wewnętrznej strony okładziny, a drugą, odpowiednio naciętą, wyklejono grzbiet. Z punktu widzenia przyjętej definicji należałoby go uznać za scyzurę (wzmacnia połączenie bloku z oprawą, jest doszyty do bloku i doklejony do wewnętrznej strony okładziny), choć element ten pełni dodatkowo funkcję wyklejenia grzbietu. W angielskiej nomenklaturze takie rozwiązanie nazywane jest wyklejeniem grzebieniowym ${ }^{28}$ (ang. comb lining), choć równie dobrze możemy mówić o scyzurze wyklejającej grzbiet.

Zaprezentowane przykłady pokazują, że samo nazywanie poszczególnych elementów przybyszowych może stanowić kłopot. Każdy składnik oprawy dodany jest przez introligatora $\mathrm{w}$ jakimś celu i pełni określoną funkcję. Przykłady kart przybyszowych stosowanych w oprawach późnogotyckich pokazują, że jeden element oprawy mógł pełnić wiele funkcji, a tę samą funkcję mogły pełnić różne elementy — stąd problemy w próbach zaklasyfikowania poszczególnych komponentów. W skrajnych przypadkach, gdy stykamy się z przykładami wymykającymi się klasyfikacji, pozostaje nam jedynie opisać formę i funkcję danego elementu w oprawie, podziwiając ponadprzeciętną pomysłowość dawnych introligatorów.

\section{EWA CHLEBUS}

\section{ELEMENTS ADDED TO LATE GOTHIC BINDINGS — FORMS, FUNCTIONS, TERMINOLOGY}

\section{Summary}

Using late Gothic bindings as examples, the author of the article examines terminological problems associated with leaves or fragments of leaves added to books during binding. She defines the various elements, i.e. pastedowns, flyleaves, sewing guards, guards or spine linings. The aim of the article is to demonstrate the variety of solutions used by bookbinders as well as various functions of the binding elements. Particular emphasis is put on cases that question or at least encourage reconsideration of the definitions of these elements.

KEY WORDS: bookbinding, Gothic binding, added elements, added leaves, pastedowns, flyleaves

${ }^{28}$ Wyklejenie grzebieniowe nie musi być jednak doszyte do bloku. Ibidem, s. 146. 